\title{
The characterisation of natural organic matter in ground water using rapid fractionation
}

\author{
R. Albrektiene ${ }^{1}$, M. Rimeika ${ }^{1}$ \& V. Voisniene ${ }^{2}$ \\ ${ }^{I}$ Department of Water Management, \\ Vilnius Gediminas Technical University, Lithuania \\ ${ }^{2}$ Department of Chemistry and Bioengineering, \\ Vilnius Gediminas Technical University, Lithuania
}

\begin{abstract}
Natural organic matters are very common in surface and ground water, which are used for the preparation of drinking water. These compounds should be removed from water before it is ready for public consumption, whereas during the process of water disinfection natural organic matters tend to constitute disinfection byproducts. In order to choose an appropriate method for the removal of natural organic matters from water, the first objective is to find out the type of organic matters prevailing in water by using the method of rapid fractionation. The aim of this study is to identify fraction of organic compounds in groundwater and to choose the most appropriate water treatment technology. Wellfields on the coast of the Baltic Sea, surrounded by large water bodies on both sides, were chosen for the analysis. It was found that very hydrophobic acids (VHA) fraction forms the major part of organic compounds (approximately 70\%) in the groundwater from Nida and Preila-Pervalka (Lithuania) wellfields. The results of rapid fractionation performed after the process of coagulation show that the highest removal efficiency is achieved in respect of the organic compounds of VHA fraction (in Preila-Pervalka - 54\%, Nida - 64\%).

Keywords: ground water, natural organic matters, rapid fractionation, coagulation.
\end{abstract}

\section{Introduction}

Natural organic matter (NOM) occurs in an insoluble, soluble and colloidal form. Natural organic matter in both ground and surface water consists of a complex heterogenic mixture including humic or fulvic acids, low molecular 
weight organic acids, carbohydrates, proteins and compounds of other classes [1]. Organic matter in the environment can be divided into two main classes of compounds: non-humic substances, such as proteins, polysaccharides, nucleic acids, amino acids and others, and humic substances [2]. Humic substances are classified into humic acids, fulvic acids and humines [3]. Humic substances, namely humic and fulvicacids represent from 40 to $80 \%$ of soluble and colloidal organic substances [4]. These humic substances result from plant and animal degradation [5]. NOM provides an unpleasant taste and odour to water, also humic acids provide colour to water. A high NOM content in water can result in increased microbiological pollution of water. Reaction between NOM and reagents (chlorine) used for water disinfection produces toxic disinfection by-products (DBPs), for example haloacetic acids (HAAs), trihalomethanes (THMs), haloacetonitriles, and 3-chlor-4-(dichlormetil)-5hydroxy-2(5H)-furans [6]. These disinfection by-products contain carcinogenic or other properties harmful to the human organism, cause cancer or reproduction and development disorders [7]. It is therefore particularly important to remove these compounds from water before disinfection. The larger the amount of organic compounds in water the more difficult it is to remove iron, manganese and ammonium from water. First, organic compounds form a film over the granules of granular filter media, which reduces filtration efficiency of the media. Also, organic compounds can form complex compounds with metals. In addition, if water is rich in organic compounds, they rapidly consume oxygen and its remaining amount is insufficient for the oxidation of other elements such as iron, manganese and ammonium.

In order to effectively remove NOM from water, first it is necessary to identify the types of compounds that are predominant in water. The most important indicator for organic substance in groundwater is the total organic carbon (TOC) concentration. It has been determined that by employing the physical and chemical NOM fractionation at different $\mathrm{pH}$ values organic compounds can be divided into hydrophobic and hydrophilic [8]. In their paper Chow et al. [9] presented data of fractionation tests which used three different types of resin: DAX-8, XAD-8 and IRA-958; and four fractions of organic compounds were selected: very hydrophobic acids (VHA), slightly hydrophobic acids (SHA), hydrophilic charged (CHA) and hydrophilic neutral (NEU). Buchanan et al. [10] maintain that the types of prevailing functional groups in a certain fraction can be determined according to these fractions, for example hydrophobic fractions contain larger amounts of aromatic compounds than hydrophilic fractions. According to Croue [11], organic compounds having a higher molecular mass and a larger number of aromatic rings are much more hydrophobic.

Nida and Preila-Pervalka wellfields are located in Lithuania's Curonian Spit, which is surrounded by the Baltic Sea from one side and by the Curonian Lagoon from the other. Nida and Preila-Pervalka wellfields belong to the group of open-type wellfields. These are the wellfields that operate open-top groundwater aquifers. These wellfields belong to subgroup IIIb as they are in close proximity to surface water sources, i.e. the lagoon. In Nida wellfield the 
groundwater level settles at a depth of 2 to $5 \mathrm{~m}$, while on the shore of the lagoon it actually coincides with the level of lagoon water. The aquifer consists of medium-sized and fine particles of deep sea-eolian sand, and is 14 to $20 \mathrm{~m}$ thick. The groundwater aquifer operated by Preila-Pervalka wellfield is composed of two parts separated by a 1-3 m thick gyttja layer having low water permeability occurring at a depth of 7-12 m. The upper part, around $7 \mathrm{~m}$ thick, is formed of well-sorted sand of medium particles, while the lower (around $15 \mathrm{~m}$ ) - of variously sized particles.
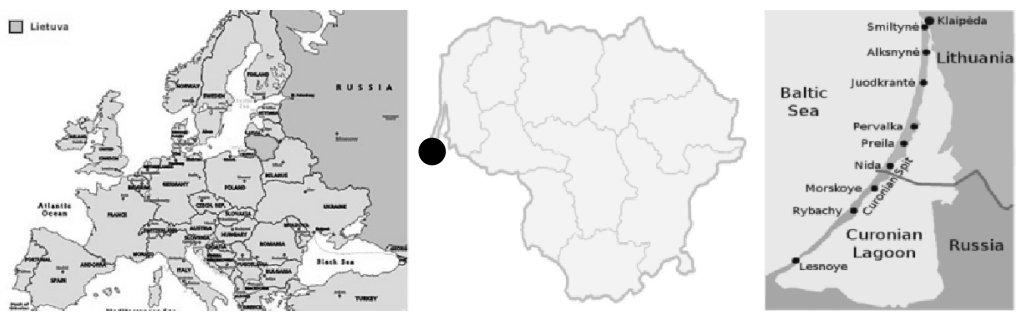

Figure 1: Wellfields.

The concentrations of iron, manganese, ammonium and organic compounds are increased in these wellfields. According to Klimas [12], no pollution source is present in these wellfields and these compounds emerge in water from groundwater accumulated in deep sea sediments. Removal of iron and manganese compounds and ammonium ions is ineffective using usual technologies for removing these compounds from groundwater (water aeration and filtration through granular filter media) when concentrations of organic compounds in groundwater are high. The contents of the total organic carbon in the water of Preila-Pervalka and Nida wellfields are large $(5.6-7.1 \mathrm{mg} / \mathrm{l}$ and 9.6-9.7 $\mathrm{mg} / \mathrm{l})$. In this case it is necessary to remove organic compounds from water in order not to complicate the removal of iron, manganese and ammonium. However, in order to effectively remove organic compounds, it is first necessary to determine what types of organic compounds are prevailing in that water and afterward select the most appropriate technique for their removal. A rapid fractionation technique is used to characterise organic compounds.

\section{Materials and methods}

Groundwater from Nida and Preila-Pervalka drilled wells was used for tests. Samples were taken in October-November 2011 and February-March 2012. Water samples, of 201 each, were transported to the Norwegian Science and Technology University Water Laboratoryand to the Vilnius Gediminas Technical University Laboratory of Water Management. Water samples were stored in refrigerating containers maintaining a temperature of up to $5^{\circ} \mathrm{C}$. Sample transportation took 1 to 3 days. Groundwater quality indicators are presented in Table 1. 
Table 1: $\quad$ Groundwater quality indicators.

\begin{tabular}{|l|c|c|}
\hline \multirow{2}{*}{ Indicator } & Preila-Pervalka & Nida \\
\cline { 2 - 3 } & Average* & Average* \\
\hline $\mathrm{pH}$ & $6.68 \pm 0.09$ & $7.55 \pm 0.06$ \\
\hline Alkalinity, mmol/1 & $0.81 \pm 0.056$ & $2.17 \pm 0.07$ \\
\hline Turbidity, NTU & $50.2 \pm 0.32$ & $4.1 \pm 0.02$ \\
\hline Conductivity, $\mu \mathrm{S} / \mathrm{cm}$ & $147 \pm 0.00$ & $240 \pm 0.71$ \\
\hline Total iron, $\mu \mathrm{g} / \mathrm{l}$ & $2976 \pm 163$ & $3170 \pm 54$ \\
\hline Manganese, $\mu \mathrm{g} / \mathrm{l}$ & $215 \pm 5$ & $255 \pm 2$ \\
\hline Ammonium, $\mathrm{mg} / 1$ & $11.4 \pm 0.9$ & $1.4 \pm 0.0$ \\
\hline TOC, $\mathrm{mg} / 1$ & $7.07 \pm 0.38$ & $9.57 \pm 0.18$ \\
\hline DOC, $\mathrm{mg} / \mathrm{l}$ & $5.07 \pm 0.01$ & $8.07 \pm 0.09$ \\
\hline Colour, $\mathrm{mgPt} / \mathrm{l}$ & $22.91 \pm 0.12$ & $33.26 \pm 1.92$ \\
\hline UV $254,1 / \mathrm{m}$ & $0.174 \pm 0.000$ & $0.245 \pm 0.00$ \\
\hline
\end{tabular}

*Obtained test results - the arithmetic average of the amount of concentration in three samples.

The following indicators were identified in the water samples of Nida and Preila-Pervalka wellfields: water $\mathrm{pH}$, specific electrical conductivity (SEC), turbidity, alkalinity, water colour, water UV absorption at a wavelength of 254 $\mathrm{nm}\left(\mathrm{UV}_{254}\right)$, total organic carbon (TOC), dissolved organic carbon (DOC), iron and manganese. In addition, rapid fractionation was carried out.

Water $\mathrm{pH}$ was determined with PHM 83 Autocal pHMETER, specific electrical conductivity - WTW Microprocessor Conductivity Meter LF 537, turbidity - HACH 2100 AN IS Turbidimeter, and alkalinity - Metrohm 726 Titroprocessor. To determine water colour, UV absorption and dissolved organic carbon, water samples were filtrated via membrane filters of $0.45 \mu \mathrm{m}$. Water colour was measured in a $5 \mathrm{~cm}$ cell at a wavelength of $436 \mathrm{~nm}$, while water UV absorption - in a $5 \mathrm{~cm}$ quartz sand cell at a wavelength of $254 \mathrm{~nm}$ by Hitachi U-3000 Spectrophotometer and spectrophotometer Genesys 10VIS. The total organic carbon and the dissolved organic carbon were determined by organic carbon analyser Tekmar Dohrmann Apollo 9000 (USA). These water tests were carried out at the Norwegian Science and Technology University Water Laboratory and the Vilnius Gediminas Technical University Laboratory of Water Management. Total iron, manganese and ammonium were analysed using spectrophotometer Genesys VT10 at the Drinking Water Laboratory of UAB Vilniaus vandenys.

The fractionation procedure was based on the studies carried out by Croue et al. [13] and Bolto et al. [14] during which different fractions of organic compounds were absorbed using different types of resin. With the help of three 
different types of resin four different fractions of organic compounds were selected: very hydrophobic acids (VHA), slightly hydrophobic acids (SHA), hydrophilic charged (CHA) and hydrophilic neutral. For the fractionation analyses, Chow et al. [9] used three types of resins: DAX-8, XAD-8 and IRA958. Fractionation was followed by a DOC analysis. Calculation of the concentrations of fractions:

$\mathrm{VHA}=$ DOC (raw water) - DOC (water flown through DAX-8 resin);

$\mathrm{SHA}=$ DOC (water flown through pro DAX-8 resin) - DOC (water flown through XAD-8 resin);

$\mathrm{CHA}=\mathrm{DOC}$ (water flown through $\mathrm{XAD}-8$ resin) - DOC (water flown through IRA-958 resins);

$\mathrm{NEU}=$ DOC (water flown through IRA-958 resin).

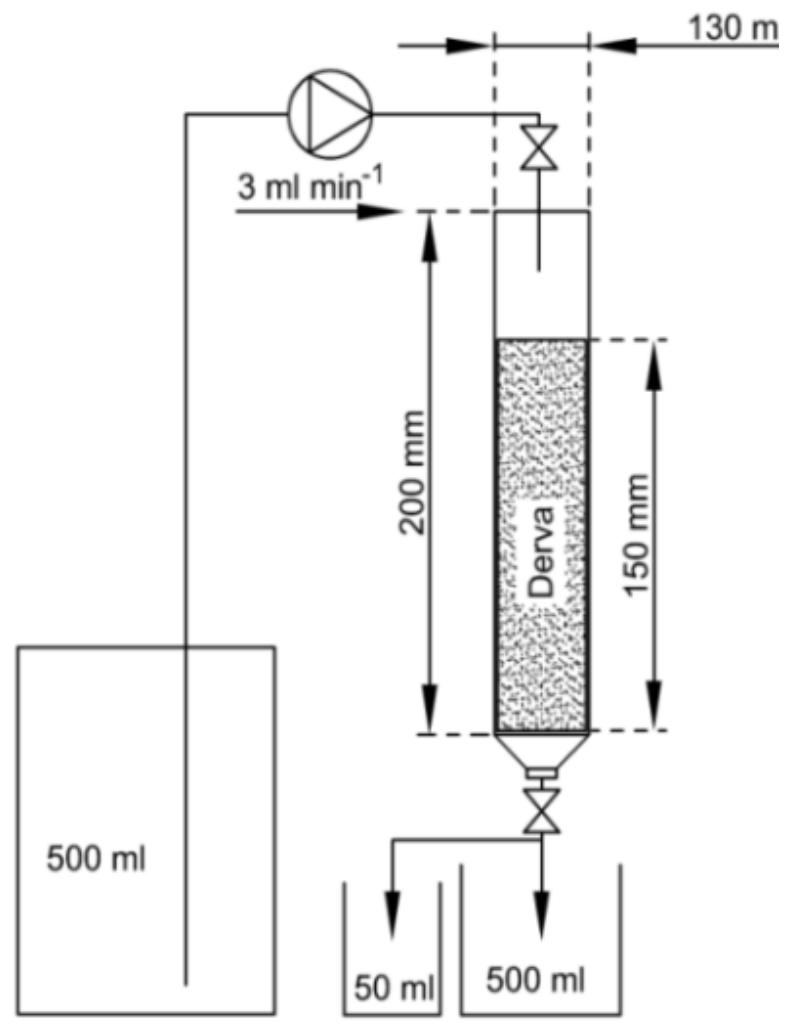

Figure 2: Layout of fractionation setup.

In addition, coagulation tests were performed. Polyaluminium chloride (PAC18. 9\% Al) was selected for coagulation. Coagulation tests were carried out when water $\mathrm{pH}$ was equal to 5.8 , and the coagulant dose $-4 \mathrm{mgAl} / \mathrm{l}$. Laboratory 
test used 11 of water containing the respective coagulant dose, which was mixed at a rate of $280 \mathrm{rev} / \mathrm{min}$ for 1 minute and at a rate of $30 \mathrm{rev} / \mathrm{min}$ for 20 minutes and afterward was left to settle for 30 minutes. After the process of coagulation water was filtrated through paper filters and a rapid fractionation was performed. Process tests were carried out three times.

The obtained test results represent the arithmetic average of concentration amounts in three samples when the difference is not greater than $5 \%$, and where the difference is greater concentrations were additionally determined.

\section{Results and discussion}

The results obtained during rapid fractionation of the water samples taken from Nida and Preila-Pervalkawellfields are presented in Figure 3. Both tested samples were fractionated and after fractionation the analyses of dissolved organic carbon, colour and UV absorption were carried out.

It follows from the performed rapid fractionation tests that the major part of organic compounds in the groundwater of drilled wells in both Nida and PreilaPervalka wellfields is made of the VHA fraction (Preila-Pervalka $-3.53 \mathrm{mg} / \mathrm{l}$ $(70 \%)$, Nida $-5.62 \mathrm{mg} / \mathrm{l}(70 \%))$. This means that groundwater is dominated by fulvic acids, part of humic substances, aliphatic carboxylic acids and aromatic compounds. These are high-molecular hydrophobic humic compounds that can be easily removed by coagulation. The measurements of water colour and UV absorption at a wavelength of $254 \mathrm{~nm}$ performed after fractionation also show that the most intense colour of water samples is in the VHA fraction and, respectively the highest absorption - at $254 \mathrm{~nm}$ wavelength. These data also confirm that the water samples concerned are dominated by aromatic compounds, as aromatic compounds are best absorbed at a wavelength of 254 $\mathrm{nm}$. The content of organic compounds in the CHA fraction in the groundwater of Nida wellfield is $0.70 \mathrm{mg} / \mathrm{l}$, and in Preila-Pervalka water $-0.28 \mathrm{mg} / \mathrm{l}$. The compounds of this fraction are still absorbed at a wavelength of $254 \mathrm{~nm}$ (Nida $0.0141 / \mathrm{m}$, Preila-Pervalka $-0.0081 / \mathrm{m}$ ). However, organic compounds of this fraction no longer provide colour to water. The NEU fraction constitutes the smallest share of organic compounds. Organic compounds are slightly absorbed at a UV wavelength of $254 \mathrm{~nm}$, but they do not provide colour to water any longer. This fraction of organic compounds is composed of short-chain aliphatic amines, alcohols, ketones and esters. According to Chow et al. [9], these organic compounds are most difficult to remove using coagulation. These fractions are difficult to remove through coagulation because their molecular mass is lower and they are hydrophilic, while such organic compounds cannot be removed by coagulation. As maintained by Soh et al. [15], these compounds have a potential to form disinfection by-products which are harmful to human health.

In order to identify which types of organic compound fractions can be most efficiently removed during the process of coagulation, fractionation after the process of coagulation is carried out. Coagulation tests are carried out using a polyaluminium chloride dose of $4 \mathrm{mgAl} / \mathrm{l}$ in the water of Nida and Preila-Pervalka wellfields. Test results are presented in Figure 4. 

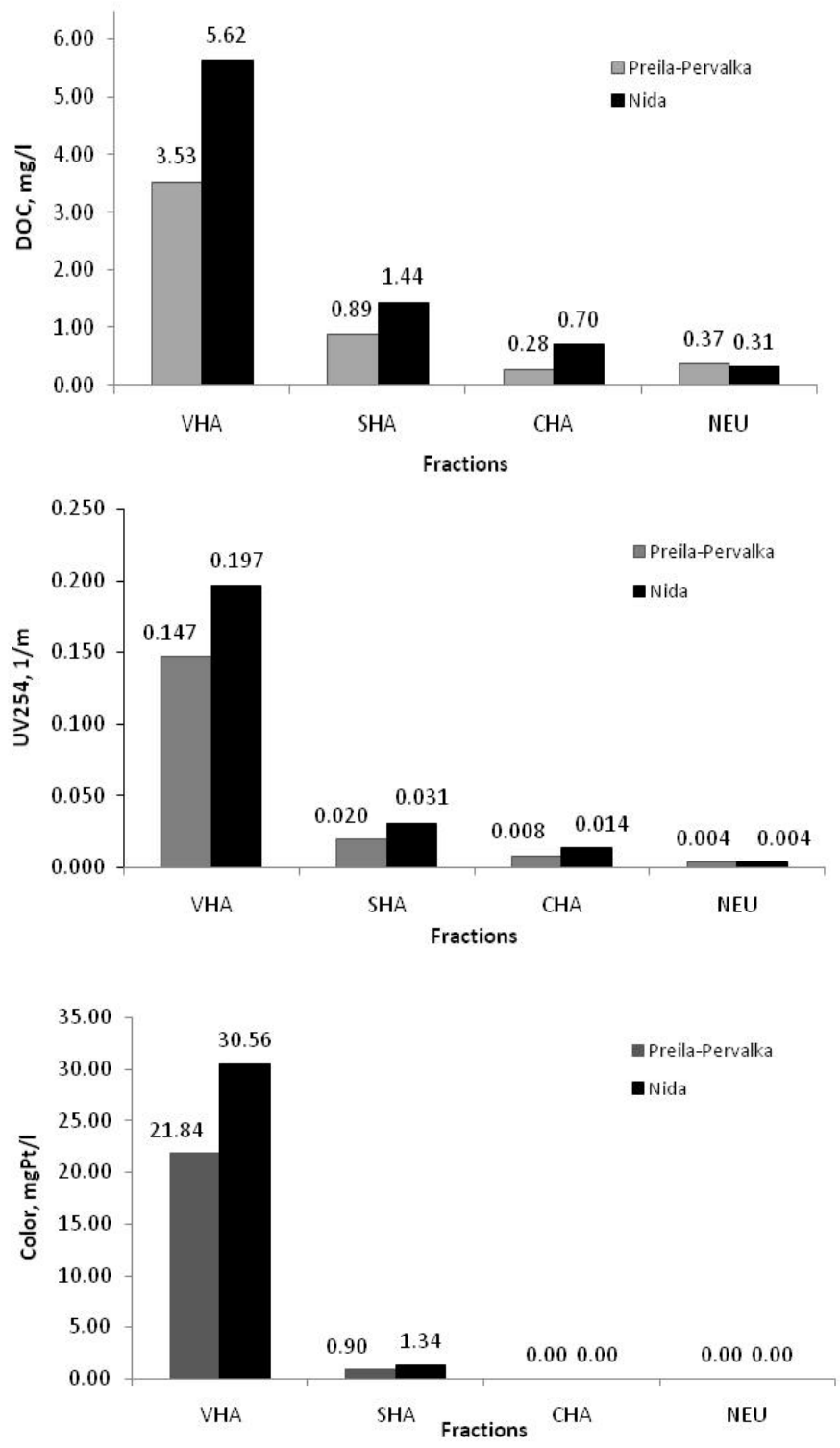

Figure 3: Fractions of organic compounds in the groundwater of Nida and Preila-Pervalka drilled wells. 

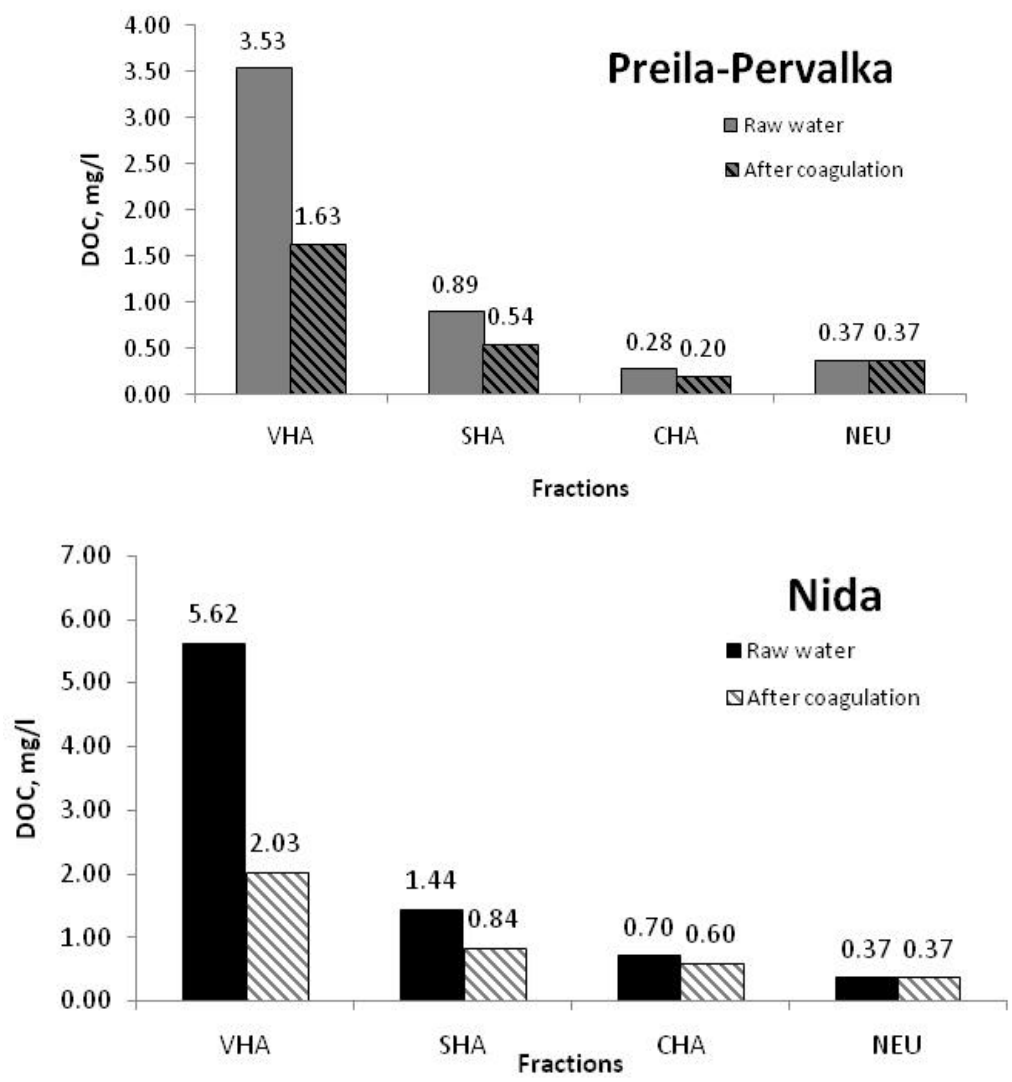

Figure 4: Results of fractionation after coagulation.

The results of rapid fractionation carried out before and after coagulation show that concentrations of all organic compound fractions, except NEU, are reduced during coagulation. Since VHA fraction compounds constitute the largest fraction of organic compounds in water, as Figure 4 shows, coagulation leads to a drop in their concentration from 3.53 to $1.63 \mathrm{mg} / \mathrm{l}$ in Preila-Pervalka, and from 5.62 to $2.03 \mathrm{mg} / \mathrm{l}$ in Nida. As regards SHA fraction removal, the fraction of these organic compounds in Preila-Pervalka water decreased 39\%, while in Nida water $-41 \%$. While removing CHA fraction organic compounds, the removal efficiency in the water of Preila-Pervalka wellfield represented $29 \%$, while in Nida $-14 \%$. The NEU organic compound fraction is not removed during the process of coagulation. The results of these tests lead to the conclusion that the compounds of very hydrophobic acid fraction are most efficiently removed by coagulation. Since the compounds of very hydrophobic acid fraction are prevailing in the groundwater of all wellfields at issue, this means that coagulation is an appropriate technique for removing organic compounds from groundwater. 


\section{Conclusions}

The groundwater of Nida and Preila-Pervalka wellfields is rich in organic compounds. By employing a rapid fractionation technique, it has been determined during tests that the VHA fraction accounts for the major share of organic compounds in these waters (in Nida - 70\%, in Preila-Pervalka - 70\%). This means that the water samples analysed are dominated by humic and fulvic acids of an aromatic nature and high molecular mass. The results of rapid fractionation performed after the process of coagulation show that the highest removal efficiency is achieved in respect of the organic compounds of VHA fraction (in Preila-Pervalka - 54\%, Nida - 64\%). Since the compounds of the very hydrophobic acid fraction are prevailing in the groundwater of all wellfields analysed, coagulation is an appropriate technique for removing organic compounds from groundwater. The NEU organic compound fraction is not removed during the process of coagulation.

\section{Acknowledgements}

The authors thank Ltd "Neringa water" and the collective of Norwegian University Science and Technology Department of Hydraulic and Environmental Engineering for contribution and opportunity to carry out this work.

\section{References}

[1] Her, N., Amy, G., McKnight, D., Sohn, J., Yoon, Y. Characterization of DOM as a function of MW by fluorescence EEM and HPLC-SEC using UVA, DOC and Fluorescence detection. Water research 37, pp. 4295-4303, 2003.

[2] Fabris, R., Chow, Ch.W.K., Drikas, M., Eikebrokk, B. Comparison of NOM character in selected Australian and Norwegian drinking waters. Water research. 42 (2008), pp. 4188-4196, 2008.

[3] Donisa, C., Mocanu, R., Steinnes, E. Distribution of some major and minor elements between fulvic and humic acid fractions in natural soils. Geoderma 111, pp. 75-84, 2003.

[4] Muller, M.B., Fritz, W., Lankes, U., Frimel, F.H. Ultrafiltration of nonionic surfactants and dissolved organic matter. Environmental Science \& Technology 2004(38), pp. 1124-1132, 2004.

[5] Steffen, K.T., Hatakka, A., Hofrichter M. Degradation of Humic Acids by the Litter-Decomposing Basidiomycete. Collybia dryophila. Applied and Environmental Microbiology 68(7), pp. 3442-3448, 2002.

[6] Musikavong, C., Wattanachira, S., Marhaba, T.F., Pavasant, P. Reduction of organic matter and trihalomethane formation potential in reclaimed water from treated industrial estate wastewater. Journal of Hazardous Material B127, pp. 48-57, 2005.

[7] Richardson, S.D., Thruston J., A.D., Rav-Acha, C., Groisman, L., Popilevsky, I., Juraev, O., Glezer, V., McKague, A.B., Plewa, M.J., 
Wagner, E.D. Tribromopyrrole, brominated acids, and other disinfection byproducts produced by disinfection of drinking water rich in bromide. Environmental Science \& Technology 37(17), pp. 3782-3793, 2003.

[8] Leenheer, J.A. Comprehensive assessment of precursors, diagenesis, and reactivity to water treatment of dissolved and coloidal organic matter. Water Science and Technology: Water Supply 4(4), pp. 1-9, 2004.

[9] Chow, Ch.W.K., Farbis, R., Drikas, M. A rapid fractionation technique to characterise natural organic matter for the optimisation or water treatment processes. Journal of Water Supply: Research and Technology - Aqua 53(2), pp. 85-92, 2004.

[10] Buchanan, W., Roddick, F., Porter, N., Drikas, M. Fractionation of UV and VUV Pretreated natural organic matter from drinking water. Environmental Science and technology 39 (12), pp. 4647-4654, 2005.

[11] Croue, J.P. Isolation, fractionation characterisation and reactive properties of natural organic matters. In Proceedings of AWWA18th Federal Conference; Adelaide, Australia, 12-14 April, 1999.

[12] Klimas, A. Vandens kokybe Lietuvos vandenvietėse. Pokyčiu studija. Vilnius, p. 487, 2006.

[13] Croue, J.P., Martin, B., Deguin, A., Legube, B. Isolation and characterisation of dissolved hydrophobic and hidrophilic organic substances of a reservoir water. In: Natural Organic Matter in Drinking Water. American Water Works Association, Denver, pp. 73, 1994.

[14] Bolto, B., Abbt-Braum, G., Dixon, D., Eldridge, R., Frimmel, F., Hesse, S., King, S., Toifl, M. Experimental evaluation of cationic polyelectrolytes for removing natural organic matter from water. Water Science and Technology 40(9), pp. 71-79, 1999.

[15] Soh, Y.S., Roddick, F., van Leeuwen. The impact of alum coagulation on the character, biodegradability and disinfection by-product formation potential of reservoir natural organic matter (NOM) fraction. Water Science Technology 58, pp. 1173-1179, 2008. 